Oddelek za romanske jezike in književnosti

Filozofska fakulteta Univerze v Ljubljani

marjana.sifrar-kalan@ff.uni-lj.si

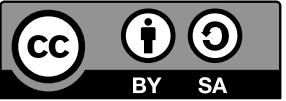

\title{
RECENZIJA UČBENIKA DIVERSO 1
}

Alonso, E., Corpas, J., Gambluch, C. (2015): Diverso 1: Curso de Español Para Jóvenes (delovni učbenik + CD). Madrid: SGEL. ISBN/EAN: 9788497788212, mehka vezava, 200 strani, 27,70 EUR

\section{OSNOVNE ZNAČILNOSTI IN PRISTOP}

Učbenik Diverso 1, ki je izšel leta 2015 pri španski založbi SGEL, glede na Skupni evropski jezikovni okvir razvija uporabnikove kompetence na ravni A1. Ciljna skupina so mladi med 15. in 20. letom, s poudarkom na srednješolcih, ki se španščino učijo kot tuji in ne kot drugi jezik v rednem šolskem programu v svoji državi. Založba je s tem pokrila manjko učbenikov za tovrstno ciljno skupino, saj je večina učbenikov namenjenih mlajšim najstnikom (upoštevajoč španski in ne srednjeevropski šolski sistem) ali odraslim. Učbenik je poleg osnovnega komunikacijskega pristopa, ki razvija štiri osnovne spretnosti branja, poslušanja, govora in pisanja, zasnovan na globalnem, medkulturnem in večjezičnem pristopu, ki vsebuje zelo močno vzgojno komponento in v učencu želi razvijati (samo)kritičnost, odgovornost, refleksijo, strpnost, solidarnost, ustvarjalnost in ekipni duh. Vsaka enota naj bi poleg učenja jezika in kulture služila razmisleku in razvijanju osnovnih človeških vrednot. Enota 1 tako razvija koncept identitete in spoštovanje različnih identitet ter poklicev; enota 2 se ukvarja z medčloveškimi odnosi in spodbuja k medsebojnemu spoštovanju kljub razlikam; enota 3 predstavlja različna bivanjska in naravna okolja in spodbuja učence k sodelovanju v skupini oz sobivanju; enota 4 govori o navadah in dnevni rutini ter spodbuja k spoštovanju rutine in reda $\mathrm{v}$ šolskem razredu; enota 5 se osredinja na koncept tekmovanja, zmage in sodelovanja; enota 6 razvija odprtost do različnih prehrambenih navad; enota 7 se ukvarja s prostim časom in $\mathrm{z}$ zabavo $\mathrm{v}$ različnih kulturah in pri učencu spodbuja ustrezno rabo interneta; enota 8 govori o vplivu vremena na vsakdanje življenje in na kulturo ter razvija sprejemanje različnih mnenj; enota 9 preko teme potovanj razvija spoštovanje različnih kultur. V vsaki enoti se pojavijo vprašanja, ki se navezujejo na učenčeva stališča, mnenja, navade, kulturne primerjave itd. ter skušajo učenca opozoriti in pripeljati do primerjave družbeno-kulturnih vidikov med lastnim in špansko govorečim svetom ter globalne primerjave na splošno. 


\section{SESTAVA UČBENIŠKEGA KOMPLETA}

Diverso 1 je učbenik in obenem delovni zvezek, kar omogoča učenčevo aktivno vlogo. K učbeniku je priložena tudi zgoščenka, ki vsebuje posnetke za delo z učbenikom in delovnim zvezkim. Učbenik vsebuje slovnične strani in besedišče, ki je razdeljeno po enotah. Sledi delovni zvezek, ki poleg vaj za utrjevanje vključuje tudi test za vsako enoto. Ker je test sestavljen iz več delov - jezik in sporazumevanje, bralno in slušno razumevanje ter pisno in ustno izražanje -, se učenci že od ravni A1 pripravljajo tudi na maturo. Ne le test za samovrednotenje, pač pa celoten učbeniški komplet uravnoteženo razvija štiri osnovne spretnosti. Za čim bolj optimalno in učinkovito učenje in kot dopolnilo slušnim posnetkom, ki jih je sicer dovolj, a ne veliko, so na youtubu na voljo izredno simpatični video posnetki, v katerih z veliko smisla za humor mladi (15-20 let) v obliki video bloga predstavljajo vsebine vsake enote učbenika. Prepričana sem, da bo to zelo učinkovito motivacijsko in učno sredstvo. Slušni in video posnetki vključujejo govorce različnih španskih dialektov (npr. argentinski, venezuelski, kolumbijski itd.). Učbenik ne vsebuje eksplicitnega poučevanja učnih strategij, razen v kazalu, kjer so naštete uporabljene strategije po enotah. V učbeniškem delu prevladujejo kognitivne strategije, kot npr. ugibanje, sklepanje in bralne strategije, v "delovnem zvezku" (drugi del učbenika) pa skupinjenje kot učna strategija za učenje besedišča. Razvijanje ostalih učnih strategij bo prepuščeno učitelju.

\section{ZGRADBA}

Učbenik se začne s predpoglavjem, v katerem učenci spoznajo osnovne pozdrave, abecedo (preko imen španskih in hispanoameriških mest ter držav), številke, osnovno besedišče za delo v razredu in nekaj španskih besed, ki jih verjetno že poznajo (el español internacional) ter zemljevid Latinske Amerike.

Vsebinskih poglavij je devet. Vsako ima 10 strani. Zgradba vsake enote je podobna drugim sodobnim učbenikom za poučevanje tujih jezikov. Namen prve strani enote je učenca seznaniti s temo in cilji, ga motivirati in temo povezati z njegovim predznanjem ali vedenjem o svetu. Sledi šest strani jezikovnega vnosa preko pisnih in slušnih besedil, shem in slikovnega gradiva. V shemah so predstavljene komunikacijske funkcije, slovnica in besedišče ter pravila pravopisa in izgovorjave. Beseda "repasa" učenca opozori, kaj mora ponoviti iz prejšnje enote, da bo lahko znanje nadgradil, z besedo "avanza" pa ponudi nadgradnjo neke vaje. $S$ tem učbenik opozarja na utrjevanje in povezovanje snovi ter omogoča dodatne vaje za hitrejše in sposobnejše učence. Osma in deveta stran sta namenjeni predstavitvi špansko govorečih dežel, in to vedno z vidika teme enote. Zadnja stran "Acción - Reflexión" je namenjena delu v skupini in izdelavi ter predstavitvi manjšega projekta (npr. priprava menija, izleta, posterja, kviza ...). Sledijo vprašanja za diskusijo o odnosih in vrednotah ter o učenčevih stališčih in mnenjih. 


\section{OBLIKA}

Format učbenika je A4 in je narejen za aktivno uporabo, učenci vanj pišejo in rešujejo naloge. Za odgovore je namenjenega dovolj prostora, le za daljše pisne izdelke ga ni. Videz učbenika je privlačen in barvno zelo sistematičen (modra barva za sheme in sezname z besediščem, zelena za slovnico, roza za komunikacijske funkcije, oranžna za pravopis in izgovorjavo). Slikovno gradivo je razdeljeno po celi enoti in služi učenju in ne dekoraciji. Oblika učbenika ni sama sebi namen.

\section{TEME}

Teme so podobne kot $\mathrm{v}$ drugih učbenikih za začetno poučevanje tujega jezika, le da v tem učbeniku niso predstavljene stereotipno. Prevladuje medkulturni pristop. Obravnavane teme uravnoteženo prikazujejo življenje v Španiji in Latinski Ameriki, ponekod pa vključujejo tudi primere drugih kultur in hkrati nudijo možnost medpredmetnih povezav z geografijo, državljansko in domovinsko vzgojo, etiko itd. (odvisno od ustvarjalnosti učiteljev). Teme si po enotah sledijo sledeče: 0 - pozdravi in osnovne besede, 1 - identiteta, 2 - medčloveški odnosi, 3 - življenjsko okolje, 4 - navade in dnevna rutina, 5 - tekmovanje in šport, 6 - prehrana, 7 - prosti čas, 8 - vreme, 9 - potovanja.

Tipologija besedil, ki je ena izmed kategorij v kazalu, je raznovrstna, od osebnih dokumentov, profilov facebooka, spletnih strani do letakov, oglasov, člankov itd. V primerjavi z nekaterimi drugimi učbeniki za poučevanje tujega jezika na ravni A1 pričujoči učbeniški komplet vsebuje veliko besedil, kar je pohvalno, saj je učenec tako deležen precej jezikovnega vnosa. Žal se avtorji niso odločili za vključitev kakšnega literarnega besedila ali besedila pesmi.

\section{BESEDIŠČE}

Besedišče ustreza ravni A1, vendar se pojavi tudi besedišče, ki sodi na višje ravni, kar zasledimo v mnogih učbenikih za učenje tujega jezika. Besedišče se uvaja na impliciten način preko bralnega in slušnega razumevanja, vendar je prisotno tudi eksplicitno poučevanje, najpogosteje v kombinaciji s slikovnim gradivom.

\section{SLOVNICA}

Slovnične strukture se uvajajo na induktiven način. Nove slovnične strukture učenci najprej spoznajo preko bralnega ali slušnega razumevanja, nato pa jih uporabljajo preko 
različnih vaj. Slovnične strukture so eksplicitno predstavljene na desni strani lista v kvadratku. Tem so namenjene še strani na koncu učbenika, kjer se ne pojavljajo glede na enote učbenika, ampak so predstavljene kot slovnične enote. Pojavljajo se različni tipi nalog; prevladujejo naloge, podrejene komunikaciji, nekaj pa je tudi nalog mehanskega tipa, ki služijo utrjevanju slovničnega pravila. Produktivne naloge se v večini primerov rešujejo ustno v paru ali pisno individualno ali v skupini. V skladu z ravnjo A1 se vseskozi uporablja sedanji glagolski čas, uvede pa se sestavljeni prihodnjik (ir a + infinitivo) in povsem na koncu učbenika tudi sestavljeni preteklik pretérito perfecto.

\section{ZAKLJUČEK}

Učbenik Diverso 1 učencu predstavi raznolike teme in ga spodbudi k premisleku in primerjavi lastne kulture $\mathrm{z}$ drugimi, predvsem ustaviti s špansko govorečimi. Njegova prednost je razvijanje medkulturne kompetence in humanističen pristop z močno vzgojno komponento. Vloga učbenika ni le poučevanje jezika in kulture ampak sočasno tudi vzgajanje mladih v odgvorne, razmišljujoče in strpne globalne državljane.

Učbenik ustreza učnemu načrtu za španščino v gimnaziji, saj učenci z njim razvijajo svoje sporazumevalne kompetence $v$ španščini na ravni A1, razvijejo kulturno zavest, pridobijo nekatere vrednote ter se samostojno spopadajo $\mathrm{z}$ novimi izzivi $\mathrm{v}$ nadaljnjem procesu. 